Research Article Plant Genetics

\title{
Reference genes for quantitative real-time PCR normalization of Cenostigma pyramidale roots under salt stress and mycorrhizal association
}

\author{
Gabriella Frosi ${ }^{1,2}$, José Ribamar Costa Ferreira-Neto ${ }^{3}$, João Pacíico Bezerra-Neto ${ }^{3}$, Laís Luana de Lima ${ }^{1}$, \\ David Anderson de Lima Morais ${ }^{4}$, Valesca Pandolfi ${ }^{3}$, Ederson Akio Kido ${ }^{3}$, Leonor Costa Maia ${ }^{5}$, Mauro \\ Guida Santos ${ }^{1 *}$ (1) and Ana Maria Benko-Iseppon ${ }^{3 *}$ (i) \\ ${ }^{1}$ Universidade Federal de Pernambuco, Departamento de Botânica, Recife, PE, Brazil. \\ ${ }^{2}$ Université de Sherbrooke, Départament de Biologie, Faculté des Sciences, Sherbrooke, QC, Canada. \\ ${ }^{3}$ Universidade Federal de Pernambuco, Departamento de Genética, Recife, PE, Brazil. \\ ${ }^{4}$ Université de Sherbrooke, Faculté des Sciences, Centre de Calcul Scientifique, Sherbrooke, QC, Canada. \\ ${ }^{5}$ Universidade Federal de Pernambuco, Departamento de Micologia, Recife, PE, Brazil.
}

\begin{abstract}
Cenostigma pyramidale is a native legume of the Brazilian semiarid region which performs symbiotic association with arbuscular mycorrhizal fungi (AMF), being an excellent model for studying genes associated with tolerance against abiotic and biotic stresses. In RT-qPCR approach, the use of reference genes is mandatory to avoid incorrect interpretation of the relative expression. This study evaluated the stability of ten candidate reference genes (CRGs) from C. pyramidale root tissues under salt stress (three collection times) and associated with AMF (three different times of salinity). The de novo transcriptome was obtained via RNA-Seq sequencing. Three algorithms were used to calculate the stability of CRGs under different conditions: (i) global (Salt, Salt+AMF, AMF and Control, and collection times), (ii) only non-inoculated plants, and (iii) AMF (only inoculated plants). HAG2, SAC1, ARP3 were the most stable CRGs for global and AMF assays, whereas HAG2, SAC1, RHS1 were the best for salt stress assay. This CRGs were used to validate the relative expression of two up-regulated transcripts in Salt2h (RAP2-3 and PIN8). Our study provides the first set of reference genes for $C$. pyramidale under salinity and AMF, supporting future researches on gene expression with this species.
\end{abstract}

Keywords: Arbuscular mycorrhizal fungi, Catingueira, RT-qPCR, RNA-Seq, salinity.

Received: November 16, 2020; Accepted: April 14, 2021.

\section{Introduction}

In the Brazilian semiarid region, there is a seasonally dry tropical forest called Caatinga. Due to the restricted and irregular rainfall, Caatinga plants are often exposed to abiotic stress, such as drought and salinity (De Albuquerque et al., 2012; Santos et al., 2014). Cenostigma pyramidale (Tul.) L.P. Queiroz (previously called Poincianella pyramidalis), popularly known as 'Catingueira', is a woody legume tree and figure as one of the most representative species in the Caatinga drylands. This species has multiple uses, such as logging and medicinal applications (Alviano et al., 2008; Vilela et al.,2020). In addition, other aspects of $C$. pyramidale have been studied, such as genetic diversity (Santos et al., 2012) and phenotypic plasticity on ecological succession gradients in the semiarid area (Falcão et al., 2015). Recent studies on this species revealed an association of arbuscular mycorrhizal fungi (AMFs) with most efficient physiological and biochemical responses under drought (Frosi et al., 2016) and salinity (Frosi et al., 2018).

Send corrrespondence to Ana Maria Benko-Iseppon. Universidade Federal de Pernambuco, Departamento de Genética, Av. Prof. Moraes Rego, 1235, CEP: 50.670-423, Recife, PE, Brazil. E-mail: ana.iseppon@gmail.com.

${ }^{*}$ These authors contributed equally to this work.
Due to such promising performance for $C$. pyramidale under the mentioned abiotic stresses, besides the contribution of AMFs, this plant species became a noteworthy target for molecular studies. In this way, our group performed RNASeq of $C$. pyramidale root tissues submitted to salinity and associated with AMFs (Frosi et al., 2021). Thus, numerous transcripts possibly involved with the tolerance response and higher physiological performance were modulated and require validation.

Quantitative reverse transcription PCR (RT-qPCR) is one of the most robust and reliable techniques for validating high-throughput gene expression studies due to its sensibility and specificity (Sinha et al., 2015). Variables such as the integrity and purity of RNA, the efficacy of reagents used in RNA extraction, sample quantification, and reverse transcription (Bustin et al., 2009) may lead to quantitative and qualitative differences between the evaluated samples, demanding the selection of appropriate reference genes (RGs) for normalization of gene expression (Gutierrez et al., 2008; Wang et al., 2017). The critical point to select RGs is to verify if their expression is constitutive in the studied tissues under all evaluated conditions. The proper use of RGs ensures that the observed variation in the relative quantification of target transcripts regards changes in their expression.

Reference genes are considered "internal controls" or "calibrators" aiming to compare the different samples 
scrutinized at the same quantitative level, decreasing the probability of occurrence of false positives or negatives in terms of differential gene expression (Amorim et al., 2018). An ideal reference gene must be transcribed stably under several experimental conditions (Dheda et al., 2005). In general, RGs are related to basic cellular activities and metabolic functions, maintaining a constitutive expression under any physiological condition (Yang et al., 2014). However, several studies show that the expression of reference genes may vary according to species, tissues and external factors (Sinha et al., 2015; Amorim et al., 2018). Some RGs (such as glyceraldehyde-3-phosphate dehydrogenase, 18S ribosomal RNA, 25S ribosomal, elongation factor 1-alpha) have been widely used. However, they may show statistical variations in transcriptional modulations (Brinkhof et al., 2006; Sinha et al., 2015). Therefore, the selection of appropriate RGs is required to normalize RT-qPCR of different samples for reliable results. Given this demand, statistical algorithms such as geNorm (Vandesompele et al., 2002), NormFinder (Andersen et al., 2004) and BestKeeper (Pfaffl et al., 2004) were developed to calculate the stability and reliability of candidate RGs.

The present study provides the first selection and validation of RGs for $C$. pyramidale root tissue under salt stress and also associated with arbuscular mycorrhizal fungi (AMF), under controlled conditions. Root samples of control and saltstressed plants $(100 \mathrm{mM} \mathrm{NaCl})$, as well as non-inoculated and inoculated plants (factorial $2 \times 2$ ) at the three times (30 min, 2 $\mathrm{h}$, and 11 days) after exposure to salinity, were analyzed using the three approaches (geNorm, NormFinder, and BestKeeper) to determine the best RGs combination for each experimental condition. Finally, the statistically selected RGs were used to validate the expression of two target transcripts, which were up-regulated in Salt2h RNA-Seq libraries, reinforcing their participation in salinity response.

\section{Material and Methods}

\section{Plant material and experimental design}

The experiments were conducted in the Biosciences Center greenhouse at Federal University of Pernambuco (UFPE) $\left(8^{\circ} 08^{\prime} 58^{\prime} \mathrm{S}, 34^{\circ} 56^{\prime} 55^{\prime} \mathrm{W}\right)$ in the Brazilian Northeast region, at an average temperature of $34 \pm 2{ }^{\circ} \mathrm{C}$, a relative humidity of $40-60 \%$ and $12 \mathrm{~h} / 12 \mathrm{~h}$ of light/dark (maximum light flux: $1400 \mu \mathrm{mol} \mathrm{m} \mathrm{m}^{-2} \mathrm{~s}^{-1}$ ). Seeds of C. pyramidale were provided by Centro de Referência para Recuperação de Áreas Degradadas (CRAD) (Petrolina, Pernambuco, Brazil). The experimental design, the growth conditions, the arbuscular mycorrhizal fungi (AMFs) inoculation process, and physiological data are described in Frosi et al. (2018).

In summary, 20-days-old seedlings were transferred to $100 \mathrm{ml}$ pots with sterilized soil. The soil was collected in the Pernambuco state, Brazilian Northeast $\left(7^{\circ} 35^{\prime} 39^{\prime} \mathrm{S}\right.$, $34^{\circ} 54^{\prime} 23^{\prime} \mathrm{W}$ ) and was classified as dystrophic yellow Latosol. Seedlings destined for inoculation received soil inoculum with 150 spores from Acaulospora longula Spain \& N.C. Schenck (URM AMF 07) and Claroideoglomus etunicatum (W.N. Becker \& Gerd.) C. Walker \& A. Schüßler (URM AMF 03), provided by the Mycorrhizas Laboratory's Inoculum Bank at the Mycology Department of UFPE, totaling 300 spores per plant. Non-inoculated plants received the same amount of autoclaved rhizosphere soil. After 30 days under these conditions, the plants were transferred to pots containing $5 \mathrm{~kg}$ of same soil type with a phosphorus (P) concentration adjusted to $33 \mathrm{mg} \mathrm{dm}^{-3}$ by applying simple superphosphate $\left(\mathrm{P}_{2} \mathrm{O}_{5}\right)$ in all treatments for standardization. This concentration was determined by Frosi et al. (2016), in which $33 \mathrm{mg} \mathrm{dm}^{-3}$ of $\mathrm{P}$ in the soil promoted higher gains in plant biomass in this species under well-watered conditions.

The plants were kept under hydration (pot capacity - 300 $\mathrm{mL}$ ) until six months of age, when the salt stress was imposed by saline irrigation with $300 \mathrm{~mL}$ of $\mathrm{NaCl}(100 \mathrm{mM})$ solution at 08:00 am, every day, for 11 days. This concentration is sufficient to achieve a soil electrical conductivity above $2 \mathrm{mS}$ $\mathrm{cm}^{-1}$, characterizing the soil as saline (US Salinity Laboratory 1954). The 11th day was the maximum stress, considering that the photosynthetic rates were close to zero (see Frosi et al., 2018). The experimental design was performed in $2 \mathrm{x}$ 2 factorial (presence or absence of salt and AMF), totaling four treatments: 1) Control (Ct); 2) AMF; 3) Salt and 4) $\mathrm{AMF}+$ Salt. When the stress started, the paired collections of salt/inoculated treatments were carried out with their respective controls. The collection times were: $30 \mathrm{~min}, 2 \mathrm{~h}$, and 11 days after the start of saline irrigation. Roots were harvested from three biological replicates per collection time by treatment (each replicate was represented by one plant), with $\mathrm{Ct} 30 \mathrm{~min}$ used as $\mathrm{Ct} 2 \mathrm{~h}$. Root samples were frozen in liquid nitrogen and stored at $-80^{\circ} \mathrm{C}$ until RNA isolation.

\section{Total RNA Isolation, cDNA synthesis and sequencing}

The total RNA was isolated from samples using a modified lithium chloride protocol (Chang et al., 1993). DNA contaminant was removed by treatment with DNase I (Ambion, USA) according to the manufacturer's instruction. The integrity of total RNA samples was verified by performing $1.5 \%(\mathrm{w} / \mathrm{v})$ agarose gel electrophoresis, and the quantity and quality of RNA were measured using a Qubit 2.0 Fluorometer (Invitrogen, USA). An aliquot of $0.5 \mu \mathrm{g}$ of the RNA (of all replicates) was used for the cDNA synthesis using the kit ImProm-IITM Reverse Transcription System (Promega Fitchburg WI, USA), according to the manufacturer's instructions. The cDNA samples were used as template for RT-qPCR reactions.

Another aliquot of this total RNA $(3 \mu \mathrm{g})$ was sent to the Center of Functional Genomics (ESALQ/USP, Piracicaba, Brazil) for RNA-Seq libraries synthesis and sequencing. A Bioanalyzer (Agilent) was used to perform a final assessment on the quality prior to RNA-Seq sequencing. The cDNA libraries of control (Ct30min and Ct11d); Salt (30min, 2h, and 11d) and AMF (30min) treatments (three biological replicates from each sample) were generated and sequenced on the Illumina HiSeq 2500 instrument, resulting in 18 RNA-Seq libraries (paired-end, 2 x $100 \mathrm{bp}$ ).

\section{Transcriptome assembly and annotation}

After removing adapters, removing low-quality and contaminated sequences, the high-quality [Phred values $\geq 30$ (Q30)] reads were subjected to de novo assembly. The quality of the sequences was evaluated using FastQC0.11.8 tool 
(Andrews, 2010). For assembling and data analysis, we used the RNA-Seq de novo pipeline version 3.1.3 developed by Bourgey et al. (2018). Raw reads were parsed through quality filtration by Trimomatic 0.36 (Bolger et al., 2014) with the following parameters: HEADCROP:13, TRAILING:30, MINLEN:32. Trinity software 2.0.4 was used for our de novo transcriptome assembly (Haas et al., 2013). Transdecoder 2.0.1 (https://github.Com/transdecoder/transdecoder/wiki) was used to identify candidate coding regions within the generated transcriptome and to look for open reading frames (ORFs). Trinotate 2.0.2 was used to carry out functional annotation of the transcriptome using the Trinity generated transcriptome file, while transdecoder generated peptide sequence file for final candidate ORFs. Differentially expressed transcripts (for each comparison) were identified by applying the Bioconductor (Huber et al., 2015) program Empirical Analysis of Digital Gene Expression in R (edgeR) (Robinson et al., 2009).

The RNA-Seq data generated in this study were submitted to the Sequence Read Archive (SRA) of NCBI under the accession numbers: PRJNA552047; BioProject: PRJNA552047 and BioSample: SAMN12173571 (https://www. ncbi.nlm.nih.gov/Traces/study/?acc=PRJNA552047). The assembled transcriptome was submitted to the Transcriptome Shotgun Assembly (TSA) of NCBI. This Transcriptome Shotgun Assembly project has been deposited at DDBJ/EMBL/ GenBank under the accession GIYP00000000. The version described in this paper is the first version, GIYP01000000.

\section{Selection of CRGs and primer design}

In this study, CRGs were selected based on transcripts with no differential expression in all sequenced libraries (Salt30min, Salt2h, Salt11d, and AMF30min), that is, those with $\log ^{2} \mathrm{FC}$ values between 1.0 and -1.0 ( $\mathrm{p}>0.05$; false discovery rate, FDR $>0.05$ ). In order to verify the expression stability of the CRGs, target transcripts (TTs) were selected according to their functional annotation and $\log ^{2} \mathrm{FC}$ values $>$ 1.0 associated with p-values and FDRs $<0.05$ in at least one of the contrasts (Salt2h).

Primer design was performed using the Primer 3 Plus online tool (http://www.bioinformatics.nl/cgi-bin/primer3plus/ primer3plus.cgi), using the following parameters: GC content of $40-60 \%$ (ideal content of $50 \%$ ), annealing temperature of 58 $62^{\circ} \mathrm{C}$ (ideal of $60^{\circ} \mathrm{C}$ ), length primer of $18-22 \mathrm{bp}$ and amplicon size of 100-200 bp (Table 1). During primer design, regions with conserved domains/motifs were excluded to prevent primer annealing in multiple regions and, therefore, avoid isoforms amplifications. Additionally, a local BLASTn was performed using Bioedit against the transcriptome analyzed to verify that each primer pair recovered exclusively the desired transcript.

\section{RT-qPCR, amplification efficiency, and relative expression}

The RT-qPCR reactions were performed on PCR Line Gene 9600 (Bioer Hangzhou Technology, Zhejiang, China) with GoTaq ${ }^{\circledR}$ qPCR Master Mix (Promega, Fitchburg WI, USA). All reactions were prepared in three biological and technical replicates. The reactions were adjusted to $10 \mu \mathrm{L}$ reaction mixture and consisted of $5 \mu \mathrm{L}$ of GoTaq ${ }^{\circledR}$ qPCR
Master Mix 2x, $1 \mu \mathrm{L}$ of diluted cDNA (1/10), $0.3 \mu \mathrm{L}$ of each primer $(5 \mu \mathrm{M})$ and $3.4 \mu \mathrm{L}$ of ddH2O and performed as follows: $95^{\circ} \mathrm{C}$ for $2 \mathrm{~min}$, followed by 40 cycles of $95^{\circ} \mathrm{C}$ for $15 \mathrm{~s}, 62^{\circ} \mathrm{C}$ for $60 \mathrm{~s}$ and $72{ }^{\circ} \mathrm{C}$ for $15 \mathrm{~s}$. After amplification, dissociation curves were produced $\left(60-95^{\circ} \mathrm{C}\right.$ at a heating rate of $0.1^{\circ} \mathrm{C} /$ sec and acquiring fluorescence data at every $0.3^{\circ} \mathrm{C}$ ) to confirm the specificity of the primers. The amplification efficiency for each primer was calculated from a standard curve generated by cDNA serial dilutions $(1 / 10,1 / 100,1 / 1000$, and $1 / 10000)$ in triplicate, according to the following equation: $\mathrm{E}=10$ (-1/slope of the standard curve) -1 . Slopes were considered acceptable in the range of -3.58 to -3.10 for the RT-qPCR assay (Biassoni and Raso, 2014). The expression pattern of two TTs was performed on Salt30min, 2h, 11d, and AMF30min, using the most suitable RGs as normalizers according to the software used. The Relative Expression Software Tool Rest2009 (REST 2009), a standalone software tool to estimate up and down regulation, was adopted to calculate the relative expression of the TTs. The follow formula was applied: $\mathrm{E}$ ( $\Delta \mathrm{Cq}$ Target $) /$ $\mathrm{E}(\Delta \mathrm{Cq} \mathrm{RG})$; where $\mathrm{E}$ is the average efficiency for each gene; $\Delta \mathrm{Cq}$ regards the difference between mean $\mathrm{Cq}$-value of a control sample and the mean Cq-value of treated sample. This software bases its calculations on pairwise comparisons (target transcripts $\mathrm{x}$ reference genes) using randomization and bootstrapping techniques Pairwise Fixed Reallocation Randomization TestC (Pfaffl et al., 2002). Hypothesis testing $(p<0.05)$ was inferred to determine if there was a significant difference in target transcripts levels between control and treatments. The present work followed the MIQE guidelines (Minimum Information for Publication of Quantitative RealTime PCR Experiments) (Bustin et al., 2009), aiming to achieve experimental stringency and transparency of data in order to increase the reliability of the results (Table S1).

\section{Reference genes expression stability}

The expression stability of the 10 CRGs (Table 2) was analyzed by three well stablished softwares, geNorm v 3.5 (Vandesompele et al., 2002), NormFinder v. 0.953 (Andersen et al., 2004), and BestKeeper (Pfaffl et al., 2004). For geNorm and NormFinder, the raw Cq-values were transformed into relative quantities- $\mathrm{Q}=\mathrm{E} \Delta \mathrm{Cq}$, where E represents the average efficiency for each gene, $\Delta \mathrm{Cq}$ is the difference between the lowest quantification cycle (Cq-value) of a sample of a particular gene and the Cq-value of each sample in a dataset (Hellemans et al., 2007). Basically, geNorm calculates the expression stability value $(\mathrm{M})$ based on the average of the pairwise variation $(\mathrm{V})$ for each $\mathrm{CRG}$ candidate with all genes tested. The $M$ value has a default limit of $\leq 1.5$. The lowest $M$-value indicates the highest stable expression (Vandesompele et al., 2002). Besides, the software also provides an estimation of the optimal number of reference genes that must be used for normalization. Based on the geometric mean of the expression of the two most stable CRGs, the normalization factor was calculated by geNorm, and then the NFn+1 with the next most stable gene. Subsequently, the pairwise variation $(\mathrm{Vn} /$ $\mathrm{n}+1$ ) was determined out of two sequential NFs to identify the ideal number of CRGs to be used for a normalization. A normalization factor (NF) is calculated based on the geometric mean of the expression of the two most stable 
Frosi et al.

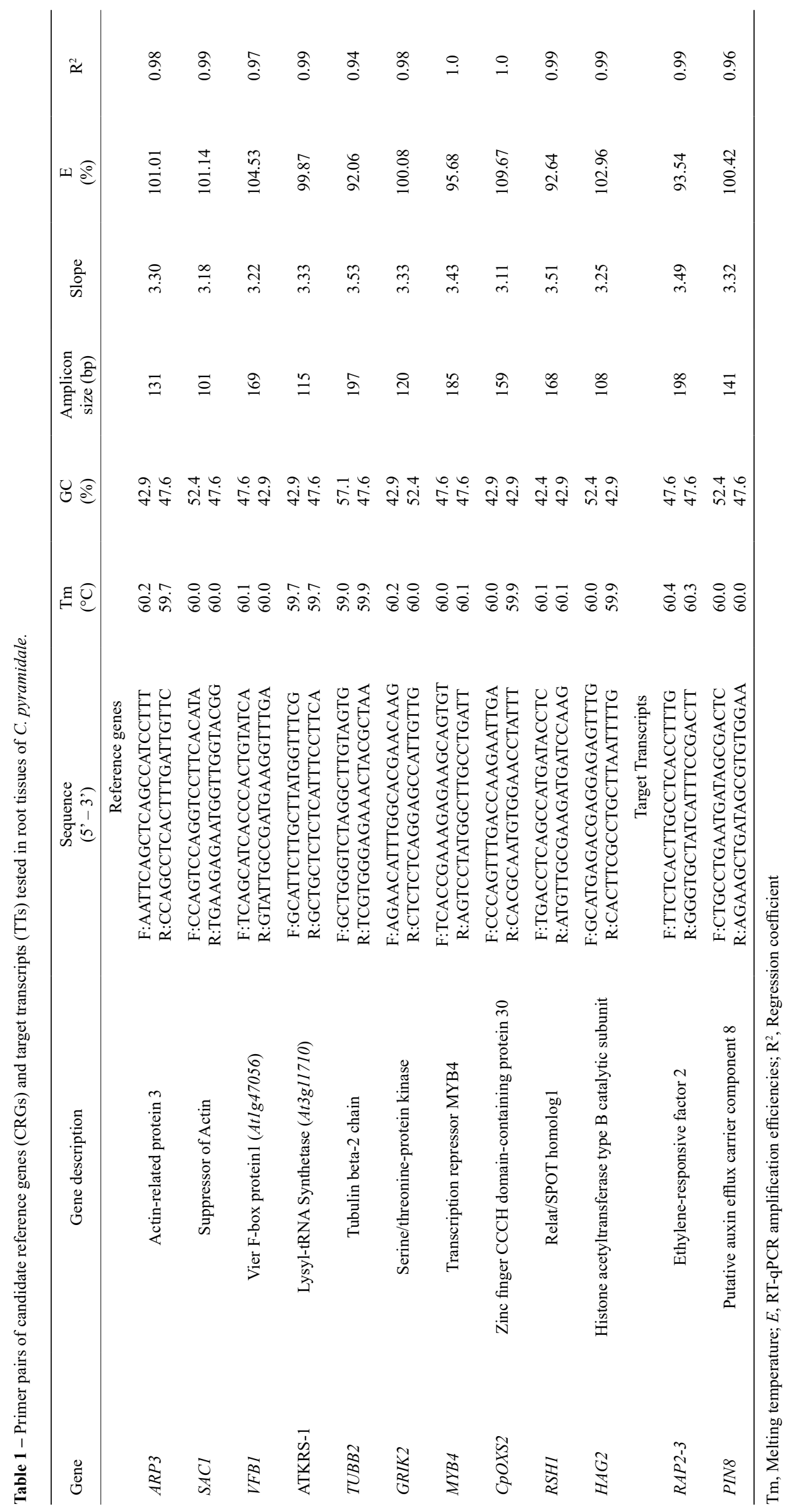


Table 2 - Expression values ( $\log _{2} \mathrm{FC}$ ) and statistical analysis (p-value) of 10 reference genes and two target genes of root transcriptome of $C$. pyramidale under salt stress and associated with arbuscular mycorrhizal fungi.

\begin{tabular}{|c|c|c|c|c|c|c|c|c|c|c|c|c|}
\hline \multirow{2}{*}{ Gene } & \multicolumn{2}{|c|}{ Control x Salt30min } & \multirow{2}{*}{ FDR } & \multicolumn{2}{|c|}{ Control x Salt $2 \mathrm{~h}$} & \multirow{2}{*}{ FDR } & \multicolumn{2}{|c|}{ Control x Salt11d } & \multirow{2}{*}{ FDR } & \multicolumn{2}{|c|}{ Control x AMF30min } & \multirow{2}{*}{ FDR } \\
\hline & $\log _{2} \mathrm{FC}$ & p-value & & $\log _{2} \mathrm{FC}$ & p-value & & $\log _{2} \mathrm{FC}$ & p-value & & $\log _{2} \mathrm{FC}$ & p-value & \\
\hline \multicolumn{13}{|c|}{ References genes } \\
\hline$A R P 3$ & 0.093 & 0.91 & 1.0 & -0.058 & 0.93 & 1.0 & -0.012 & 0.8 & 1.0 & 0.068 & 0.91 & 1.0 \\
\hline$S A C 1$ & -0.015 & 0.99 & 1.0 & -0.087 & 0.89 & 1.0 & 0.323 & 0.47 & 0.84 & -0.028 & 0.96 & 1.0 \\
\hline$V F B 1$ & -0.146 & 0.84 & 1.0 & -0.05 & 0.93 & 1.0 & 0.297 & 0.49 & 0.83 & -0.026 & 0.96 & 1.0 \\
\hline ATKRS-1 & -0.226 & 0.76 & 1.0 & 0.047 & 0.93 & 1.0 & 0.224 & 0.57 & 0.99 & 0.044 & 0.93 & 1.0 \\
\hline$T U B B 2$ & 0.002 & 1.0 & 1.0 & 0.038 & 0.95 & 1.0 & -0.782 & 0.06 & 0.3 & 0.083 & 0.88 & 1.0 \\
\hline GRIK2 & -0.253 & 0.75 & 1.0 & -0.347 & 0.56 & 1.0 & -0.125 & 0.79 & 1.0 & -0.348 & 0.56 & 1.0 \\
\hline MYB4 & 0.012 & 0.89 & 1.0 & 0.04 & 0.97 & 1.0 & 0.308 & 0.57 & 0.99 & -0.043 & 0.96 & 1.0 \\
\hline CpOXS2 & 0.014 & 1.0 & 1.0 & 0.971 & 0.53 & 1.0 & 1.817 & 0.21 & 0.56 & 0.565 & 0.71 & 0.99 \\
\hline RSH1 & 0.042 & 0.99 & 1.0 & 0.594 & 0.48 & 1.0 & -0.694 & 0.24 & 0.60 & -0.231 & 0.80 & 0.93 \\
\hline$H A G 2$ & 0.299 & 0.71 & 1.0 & 0.129 & 0.84 & 1.0 & -0.012 & 0.99 & 1.0 & 0.364 & 0.55 & 0.92 \\
\hline \multicolumn{13}{|c|}{ Target transcripts } \\
\hline$R A P 2-3$ & 0.820 & 0.26 & 0.70 & 11.266 & 0.00 & 0.01 & -0.147 & 0.71 & 0.96 & 0.311 & 0.57 & 0.94 \\
\hline PIN8 & -0.887 & 0.66 & 1.0 & 6.923 & 0.00 & 0.04 & -1.438 & 0.2 & 1.0 & 1.12 & 0.37 & 0.77 \\
\hline
\end{tabular}

RGs and then the NFn+1 with the next most stable gene. To determine the number of genes to be used for accurate normalization, the pairwise variation $(\mathrm{Vn} / \mathrm{n}+1)$ was determined out of two sequential NFs (NFn and NFn+1). The cut-off used was $\mathrm{V} \leq 0.15$, and values below it indicate that an inclusion of an additional RG is not required (Vandesompele et al., 2002).

NormFinder uses a mathematical modeling algorithm that considers the intra- and inter-group variation of the CRGs to calculates the stability values. The highest stability is associated with the lowest stability value (Andersen et al., 2004).

BestKeeper used the raw Cq-values to calculate the Pearson correlation coefficient (r), obtained by the pairwise comparison between the BestKeeper index generated by the algorithm and the CRGs. This coefficient (r) was used to represent the expression stability, where the CRGs with higher significative ( $\mathrm{p}$-value $<0.05$ ) r-value were more stable. Samples with SD-value (standard deviation) $>1$ were excluded from analysis.

The three software, geNorm, NormFinder and BestKeeper, were used to analyze and generate the CRGs stability ranking (Pfaffl et al., 2004). For this study, we analyzed three approaches: Global analysis, Salt treatments and AMF assay. In the Global analysis all treatments (Salt, AMF and both) and all collections time (30min, $2 \mathrm{~h}$, and 11d) were analyzed together. In the Salt approach, just the plants without inoculation (Salt30min, Salt2h, and Salt11d) were analyzed. For AMF assay, we analyzed all inoculated plants (AMF30min, AMF2h, AMF11d, AMF+Salt30min, $\mathrm{AMF}+\mathrm{Salt} 2 \mathrm{~h}$, and $\mathrm{AMF}+\mathrm{Salt} 1 \mathrm{~d})$. These independent approaches were analyzed using each algorithm to verify the most stable RGs for each combination.

\section{Results}

\section{Primer specificity, efficiency, and expression profile}

Ten transcripts including: Actin-Related Protein (ARP3); Suppressor of Actin ( $S A C 1$ ); F-Box Proteine ( $V F B 1)$; Lysyl-
tRNA Synthetase (ATKRS-1); Tubulin (TUBB2); Serine/ threonine-proteinkinase (GRIK2); Transcription repressor (MYB4); Zinc finger protein (CpOXS2); Relat/SPOT homolog1 $(\mathrm{RSH1})$ and Histone acetyltransferase $(H A G 2)$ were chosen as RGs candidate in RT- qPCR assays of $C$. pyramidale roots submitted to salinity and associated with AMF (Table 1). All RGs were considered to have constitutive expression $\left(1.0<\log ^{2} \mathrm{FC}<-1.0 ; \mathrm{p}>0.05 \mathrm{FDR}>0.05\right)$ in all sequenced libraries and with known function related to basal or vital cellular processes. In order to validate the selected RGs for RT-qPCR normalization, two up-regulated transcripts, Ethylene-Responsive factor (RAP2-3) and Putative Auxin efflux carrier $(P I N 8)$ in Salt $2 \mathrm{~h}\left(\log ^{2} \mathrm{FC}>1\right.$; $\mathrm{p}$-value and FDR $<0.05$ ) were used as target transcripts (TTs) (Table 2).

All primer pairs amplified a single PCR product with the expected size, as indicated by melting curves generated by RT-qPCR (Figure S1). The Tm ranged from $59.0^{\circ} \mathrm{C}$ for $T U B B 2$ to $60.3{ }^{\circ} \mathrm{C}$ for $R A P 2-3$ (Table 1). The amplification efficiencies varied from 92.06 (TUBB2) to $109.67 \%$ ( $C p O X S 2)$, the slope values ranged from 3.11 to 3.53 , and the regression coefficients (R2) were higher than 0.94 (Table 1). The $\mathrm{Cq}$ average varied from 20.97 (ARP3) to 27.88 (ATKRS-1 and GRIK2) (Figure 1; Table S2). This means that ARP3 and $A T K R S-1$ presented the highest and the lowest abundance of transcripts, respectively, for all treatments and time collections.

\section{Reference genes stability analysis}

The expression stability of the potential reference genes was analyzed using three different algorithms: geNorm, NormFinder, and BestKeeper, used to evaluate: (1) Global analysis encompassing all time collections (30 min, 2h, and 11d) and treatments (Salt and AMF); (2) Salt treatment(Salt30min, Salt2h, and Salt11d); and (3) AMF assay (AMF30min, AMF2h, $\mathrm{AMF} 11 \mathrm{~d}, \mathrm{AMF}+$ Salt30min, $\mathrm{AMF}+$ Salt2h, and AMF+Salt11d). These independent analyses were performed to rank the most stable RGs for each situation, considering each algorithm. 
According to the geNorm report, all treatments and CRGs tested showed $M$ values (gene expression stability) (Figures 2B, D, and F) below 1.5. Considering that RGs are not co-regulated, stepwise exclusion of the gene with the highest $M$ value leads to a combination of two RGs with most stable expression values among the tested samples. Thus, the four most stable genes analyzed by geNorm were $H A G 2 / S A C 1$, $A R P 3$ and RHS1 for global and AMF conditions, while HAG2/ $S A C 1, R H S 1$, and MYB4 were indicated for Salt assay (Figure $2 \mathrm{~B}, \mathrm{D}$, and F). GeNorm was also used to determine the optimal number of RGs necessary for reliable normalization, which was obtained from the "V" value analysis (a V-value below 0.15 indicates that the inclusion of an additional gene is not required for data normalization (Vandesompele et al., 2002). For all assays, $\mathrm{V}$-values below 0.15 were obtained in the second analysis (V3/V4), indicating that three RGs are required for normalization of our data via RT-qPCR (Figure 2A, C, and E).

Using NormFinder (Figure 3A), the four most stable RGs for global conditions were HAG2 (0.26), SAC1/ARP3 (0.27) and VFB1 (0.32). For the salt assay (Figure 3B), the most stable RGs were MYB4 (0.27), ARP3/SAC1 (0.28) and $H A G 2$ (0.28). In AMF assay (Figure 3C), the same four RGs were indicated, with changes only in the position: $A R P 3(0.24)$, HAG2 (0.27), SAC1 (0.30) and VFB1 (0.33).

The BestKeeper algorithm computes the Pearson correlation coefficient to define the BestKeeper index, where the CRGs with SD $<1$ and the highest Pearson coefficient of correlation (r) with the BestKeeper index present the highest stability. The global and AMF assays showed the same four most stable genes, with differences only in the second and third positions, where $H A G 2$ (0.899), SAC1 (0.884), ARP3 (0.874), and RSH1 (0.843) were the most stable RGs for the global condition, while $H A G 2$ (0.87), ARP3 (0.866), SAC1 $(0.837)$ and $R S H 1(0.818)$ were selected for the AMF condition (Table 3). For the salt condition, one gene was changed, as compared with the other conditions, where HAG2 (0.904), SAC1 (0.899), MYB4 (0.898) and RSH1 (0.878) were the four most stable RGs (Table 3).

\section{Conservation of RGs stability according to algorithm and assay}

Considering the three softwares and assays (global, salt, or AMF), there was a small variation among the first four positions (Figure 4). In the global condition, conservation of $100 \%$ was observed in the four most stable RGs (HAG2, SAC1, $A R P 3$, and $R S H 1$ ), between geNorm and BestKeeper, with no difference in their positions, while $V F B 1$ was the fourth most stably expressed according to NormFinder (showing a 75\% conservation with the remaining softwares). By contrast, $T U B B 2$ was the least stable RG considering all three softwares (Figure 4A).

Under salinity conditions, geNorm and BestKeeper had $100 \%$ conservation of the four most stable RGs (HAG2, $S A C$, RSH1, and MYB4), differing only in their rankings. In NormFinder, only one of the four most stable RGs was different (ARP3), maintaining a similarity of $75 \%$ with the other softwares (Figure 4B). Except for BestKeeper (which indicated GRIK2 as the most unstable), TUBB2 was the least stable gene indicated by geNorm and NormFinder under salinity treatments (Figure 4B).

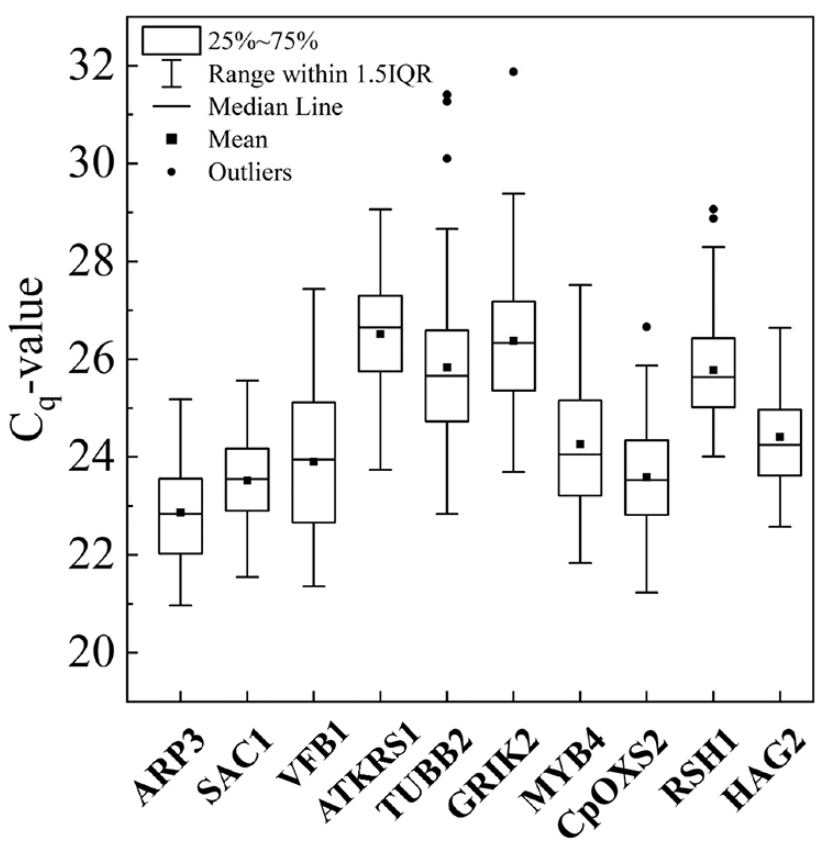

Figure 1 - Quantification cycle (Cq-value) of 10 candidate reference genes in root tissues of Cenostigma pyramidale under salt stress and associated with arbuscular mycorrhizal fungi (AMF). The Boxplot indicates the interquartile range. The solid horizontal line in the box represents the median value, and the square symbol represents the mean value. The upper and lower lines represent the maximum and minimum values. Dots indicate the outliers.

For AMF assay, there was a conservation of the four most stable RGs based on geNorm and BestKeeper ranking (HAG2, SAC1, ARP3, and RHS1), with variations only in their positions. These RGs were the same as for the global condition. In turn, for NormFinder, $75 \%$ conservation of these RGs (ARP3, HAG2, SAC1, and VFB1) was observed. Regarding the least stable gene, the three softwares diverged, being $T U B B 2$ indicated by geNorm, ATKRS- 1 by NormFinder and $M Y B 4$ by BestKeeper (Figure 4C).

Considerable conservation ( $>75 \%$ ) was observed for the four most stable RGs, for each software for the global, salt, and AMF assays. For global and AMF assays, there was a $100 \%$ conservation for the four most stable RGs in geNorm (HAG2, SAC1, ARP3, RSH1), NormFinder (HAG2, SAC1, $A R P 3, V F B 1)$ and BestKeeper (HAG2, SAC1, ARP3, RSH1). Best RGs under salt condition showed $75 \%$ conservation with global and AMF assays for geNorm (HAG2, SAC1, RSH1, MYB4), NormFinder (MYB4, ARP3, SAC1, HAG2) and BestKeeper ( $H A G 2, S A C 1, M Y B 4, R S H 1)$. For all conditions, BestKeeper and geNorm indicated the same four most stable RGs (Figure 4).

\section{Reference genes validation}

The expression patterns of two target transcripts, RAP2-3 and PIN8 (up-regulated in Salt2h), were evaluated using the three most stable RGs suggested by geNorm: $H A G 2$, $S A C 1$ and $A R P 3$ for global and AMF assay and $H A G 2, S A C 1$ and RHS1 for salt condition. The up-regulation of RAP2-3 and PIN 8 transcripts in C. pyramidale was confirmed by RT$\mathrm{qPCR}$ at Salt2h, with $\mathrm{Ct}$ values used to calculate the relative expression by REST software (Tables 2 and 4). 

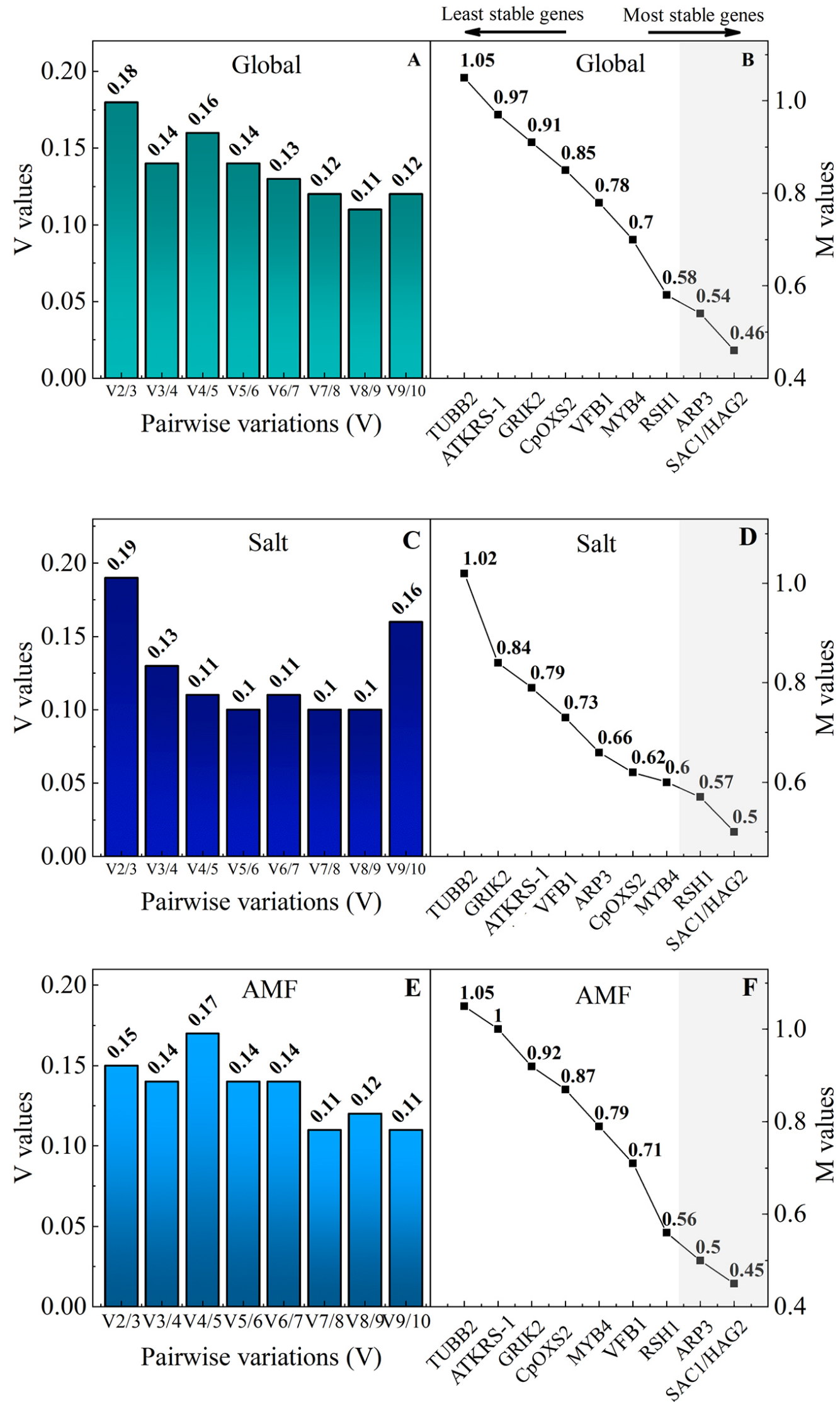

Figure 2 - Analysis of reference genes. A, C and E represent the pairwise variation analysis between normalization factors NFn and NFn +1 , indicating the optimal number of reference genes (RGs) required for reliable normalization in root tissues of Cenostigma pyramidale under salt stress and associated with arbuscular mycorrhizal fungi (AMF) for global, salt and AMF assays, respectively. B, D, and F - average expression stability (M value) of ten candidate reference genes (CRGs) for global, salt, and AMF assays, respectively. 

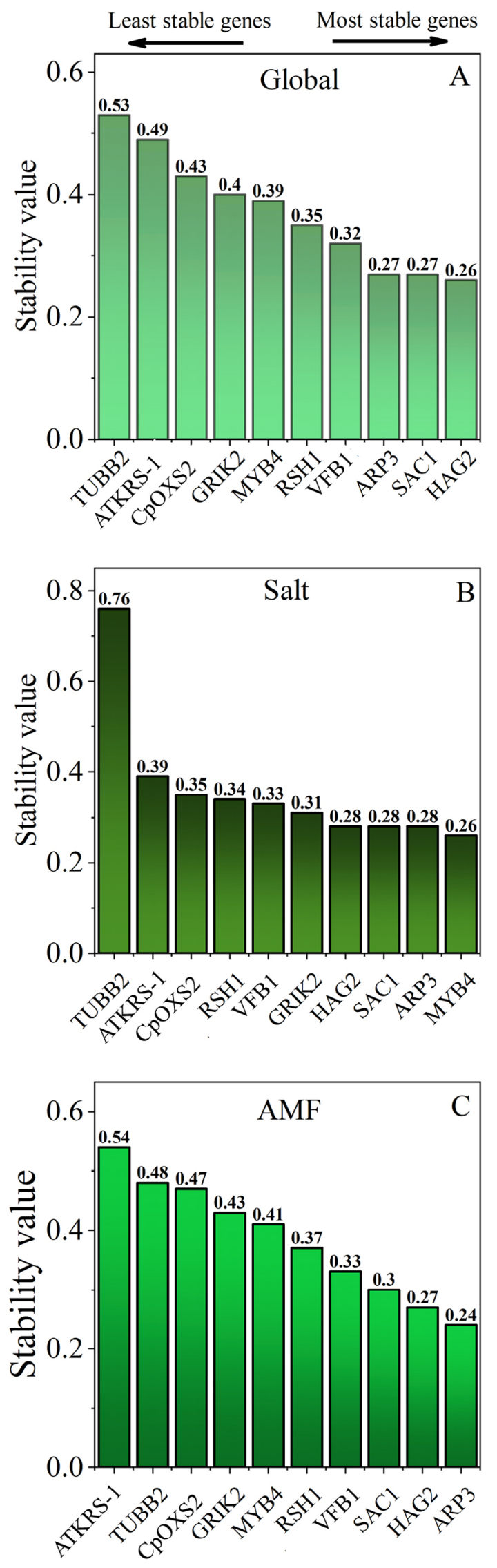

Figure 3 - NormFinder stability analysis of 10 candidate reference genes (CRGs) for analyzed assays. Lower values indicate a more stable expression. A- Global (Salt + arbuscular mycorrhizal fungi, AMF); B- Salt; C- AMF assay.

\section{Discussion}

RT-qPCR is an important approach for detecting and quantifying gene expression, being useful for transcriptomic analysis in different organisms and treatments (Huang et al., 2019; Pombo et al., 2019). However, quantification of gene expression is affected by several factors (Maroufi et al., 2010). An accurate data interpretation depends on using appropriate reference genes with minimal expression variations in tissue, treatment, or condition under analysis (Kozera and Rapacz, 2013). RT-qPCR is currently the most reliable method to validate gene expression results obtained by other high throughput methodologies, such as RNA-Seq. Thus, selecting suitable reference genes is a fundamental requirement to mitigate potential errors in RT-qPCR results (Coêlho et al., 2019). Furthermore, the use of inappropriate RGs may overestimate or underestimate the relative expression of target transcripts (Sinha et al., 2015).

The present work is the first approach related to candidate RGs in Cenostigma pyramidale, a native tolerant tree species of the Brazilian semiarid region, in response to salt stress, associated with arbuscular mycorrhizal fungi (AMF), rigorously tested for effective normalization of RT-qPCR data. The expression levels and stability of 10 RGs were evaluated in C. pyramidale roots under salt stress and inoculated with AMF at different times. To achieve this goal, we used geNorm, NormFinder and BestKeeper tools to analyze the stability of RGs in all treatments and times separately and together (global condition). Mycorrhizal colonization of plants has been studied because it promotes increases in plant growth, water, and mineral nutrient uptake, and increases plant stress tolerance under abiotic stress (Frosi et al., 2016, 2018). However, few studies have been conducted regarding the stability of RGs during mycorrhizal colonization, necessary for accurate and reliable normalization of RT-qPCR (Fuentes et al., 2016).

In our study, a $100 \%$ conservation of CRGs among the four most stable genes was pointed out by geNorm, NormFinder, and BestKeeper, for global and AMF conditions (Figures 3 and 4; Table 3). The optimal number of RGs necessary for reliable normalization was three according to geNorm, namely $H A G 2, S A C 1, A R P 3$ (Figure 2A, B, E and $\mathrm{F})$. We obtained a convergence of $75 \%$ of these four RGs for each software under salt condition compared with global and AMF conditions. Regarding the number of adequate genes to be used for normalization by geNorm for salt conditions, $H A G 2, S A C 1, R S H 1$ regarded the best combination (Figure $2 \mathrm{C}$ and $\mathrm{D})$. The RGs stability rankings often were not entirely identical for the same experimental condition, due to distinct statistical algorithms and analytical procedures for each software (Yang et al., 2015).

Reference genes obtained in our study are involved in basic cell functions. Histone acetyltransferase type B catalytic subunit (HAG2) promotes histone modification process, which plays a critical role in regulating gene expression (Pfluger and Wagner, 2008). Acetylation by histone acetyltransferases is generally correlated with increased gene activity (Chen, 2007). An extensive series of biochemical fractionation studies identified type $\mathrm{B}$ histone acetyltransferases as a distinct class of enzymes that can be found in the cytoplasm and, most importantly, with the ability to acetylate free (not nucleosomal) 
Table 3 - Ranking of 10 reference genes according BestKeeper software in global time combination of roots of C. pyramidale under salt stress and associated with arbuscular mycorrhizal fungi (AMF).

\begin{tabular}{|c|c|c|c|c|c|c|c|c|c|c|}
\hline \multirow{3}{*}{ Parameters } & \multicolumn{10}{|c|}{ Reference Genes } \\
\hline & \multicolumn{10}{|c|}{ Global } \\
\hline & $H A G 2$ & $S A C 1$ & $A R P 3$ & RSH1 & CpOXS2 & ATKRS-1 & $V F B 1$ & MYB4 & GRIK2 & $T U B B 2$ \\
\hline Standard deviation $[ \pm \mathrm{CP}]$ & 0.821 & 0.755 & 0.775 & 0.882 & 0.819 & 0.925 & 1.164 & 1.122 & 1.077 & 1.238 \\
\hline Coefficient of variation $[\% \mathrm{CP}]$ & 3.359 & 3.208 & 3.389 & 3.420 & 3.472 & 3.487 & 4.868 & 4.622 & 4.085 & 4.792 \\
\hline \multirow[t]{3}{*}{ Coefficient of correlation $[\mathrm{r}]$} & $0.899 *$ & $0.884 *$ & $0.874 *$ & $0.843 *$ & $0.734 *$ & $0.668^{*}$ & $0.902 *$ & $0.832 *$ & $0.803^{*}$ & $0.731^{*}$ \\
\hline & \multicolumn{10}{|c|}{ Salt } \\
\hline & $H A G 2$ & $S A C 1$ & MYB4 & RSH1 & $A R P 3$ & CpOXS2 & $V F B 1$ & ATKRS-1 & $T U B B 2$ & GRIK2 \\
\hline Standard deviation $[ \pm \mathrm{CP}]$ & 0.871 & 0.707 & 0.883 & 0.882 & 0.856 & 0.893 & 1.313 & 1.187 & 1.499 & 1.203 \\
\hline Coefficient of variation $[\% \mathrm{CP}]$ & 3.523 & 2.971 & 3.563 & 3.371 & 3.688 & 3.786 & 5.463 & 4.490 & 5.691 & 4.561 \\
\hline \multirow[t]{3}{*}{ Coefficient Of correlation $[\mathrm{r}]$} & $0.904^{*}$ & $0.899 *$ & $0.898^{*}$ & $0.878^{*}$ & $0.875^{*}$ & $0.845^{*}$ & $0.896^{*}$ & $0.895^{*}$ & $0.676^{*}$ & $0.875^{*}$ \\
\hline & \multicolumn{10}{|c|}{ AMF } \\
\hline & $H A G 2$ & $A R P 3$ & $S A C 1$ & RSHI & GRIK2 & CpOXS2 & ATKRS-1 & $V F B 1$ & $T U B B 2$ & MYB \\
\hline Standard deviation $[ \pm \mathrm{CP}]$ & 0.682 & 0.650 & 0.664 & 0.792 & 0.992 & 0.741 & 0.884 & 1.081 & 1.051 & 1.032 \\
\hline Coefficient of variation $[\% \mathrm{CP}]$ & 2.817 & 2.868 & 2.843 & 3.099 & 3.776 & 3.147 & 3.347 & 4.539 & 4.116 & 4.298 \\
\hline Coefficient Of correlation [r] & $0.870^{*}$ & $0.866^{*}$ & $0.837^{*}$ & $0.818^{*}$ & $0.772 *$ & $0.639^{*}$ & $0.513 *$ & $0.916^{*}$ & $0.672 *$ & $0.780 *$ \\
\hline
\end{tabular}

$\mathrm{CP}=$ Crossing point; Asterisks indicate $\mathrm{p}<0.05$

Table 4 - Relative expression calculated by REST software of two target transcripts (RAP2-3 and PIN8) for Salt30min, 2h, 11d and AMF30min in Cenostigma pyramidale roots.

\begin{tabular}{|c|c|c|c|c|c|c|}
\hline Target transcripts & Reaction efficiency & Expression & Std. error & C.I & $\mathrm{P}(\mathrm{H} 1)$ & Result \\
\hline \multicolumn{7}{|c|}{ Salt30min } \\
\hline$C P R A P 2-3$ & 0.93 & 0.659 & $0.235-4.027$ & $0.195-4.968$ & 0.787 & ns \\
\hline Cp PIN8 & 1.0 & 0.23 & $0.091-0.488$ & $0.066-1.129$ & 0.144 & ns \\
\hline \multicolumn{7}{|c|}{ Salt2h } \\
\hline CpRAP2-3 & 0.93 & 5.75 & $3.847-8.842$ & $3.273-11.777$ & 0.0 & UR \\
\hline Cp PIN8 & 1.0 & 4.49 & $1.446-11.707$ & $1.317-35.169$ & 0.015 & UR \\
\hline \multicolumn{7}{|c|}{ Salt11d } \\
\hline CpRAP2-3 & 0.93 & 0.276 & $0.176-0.443$ & $0.124-0.608$ & 0.03 & DR \\
\hline Cp PIN8 & 1.0 & 0.996 & $0.526-2.793$ & $0.278-3.389$ & 0.898 & ns \\
\hline \multicolumn{7}{|c|}{ AMF30min } \\
\hline$C p R A P 2-3$ & 0.93 & 1.506 & $1.202-2.022$ & $0.942-2.175$ & 0.101 & ns \\
\hline Cp PIN8 & 1.0 & 2.457 & $1.163-6.854$ & $0.948-7.652$ & 0.105 & ns \\
\hline
\end{tabular}

C.I (95\% Confidence Intervals); Std. Error (Standard error); P (H1): Hypothesis Test; UR (up-regulated at p < 0.05); DR (down-regulated at p $<0.05$ ); ns (not significant at the level of $\mathrm{p} \leq 0.05$ )

histones (Parthun, 2007). HAG2 is a multisubunit complex responsible for acetylating newly synthesized histone H4 on the lysines K5 and K12 (Haigney et al., 2015). Histone acetylation plays essential roles in regulating plant cell cycle, flowering time, response to environmental conditions, hormone signals, and epigenetic processes (Chen, 2007).

The second reference gene encodes a phosphoinositide phosphatase ( $S A C 1$; Suppressor of Actin 1), which regulates the levels of phosphatidyl inositol phosphates due to its phosphatase activity. In general, it is located in the endoplasmic reticulum (ER) and Golgi apparatus (GA) (Strahl and Thorner, 2007). A study performed by Despres et al. (2003) verified that three AtSAC1 proteins are located exclusively in the ER. Other phosphatases may regulate plant phosphoinositide pools in the GA. Their function was deduced based on similarity to the Saccharomyces cerevisiae SAC1 protein, which regulates the phosphatidylinositol 4-phosphate pool. Phosphoinositides are ubiquitous membrane lipids, and they play important roles in cellular processes like membrane trafficking and organization of the cytoskeleton, such as actin (Despres et al., 2003; De Craene et al., 2017). In higher plants, these lipids are also believed to be of great importance for signal transduction (Despres et al., 2003). There is evidence that plant inositol phospholipids play a role in the $\mathrm{Ca}^{2+}$ signaling pathway (DeWald, 2001). Due to its function, Hsu and Mao (2013) reported that Sac1 plays an essential housekeeping role in multicellular organisms.

The other reference gene established in our study for global and AMF condition was an actin-related protein 3 (ARP3). The organization and function of the actin cytoskeleton are regulated by several actin-binding proteins, including profilin, actin-depolymerizing factor, formin, and the Actin- 

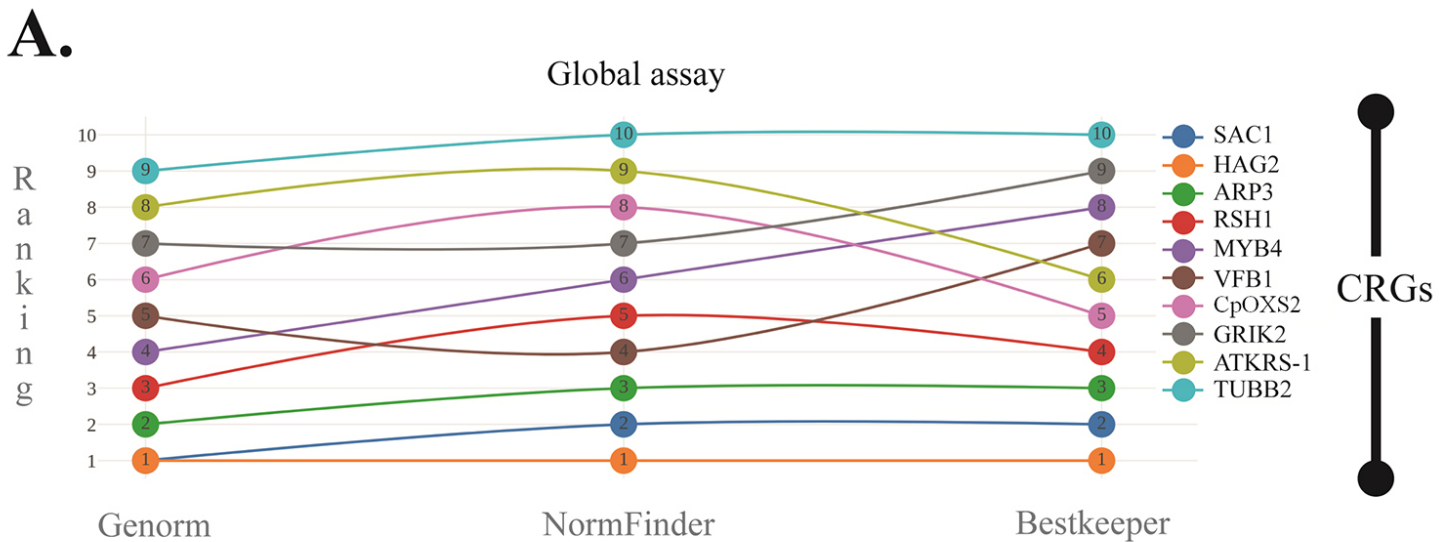

B.

Salt assay $(100 \mu \mathrm{M})$
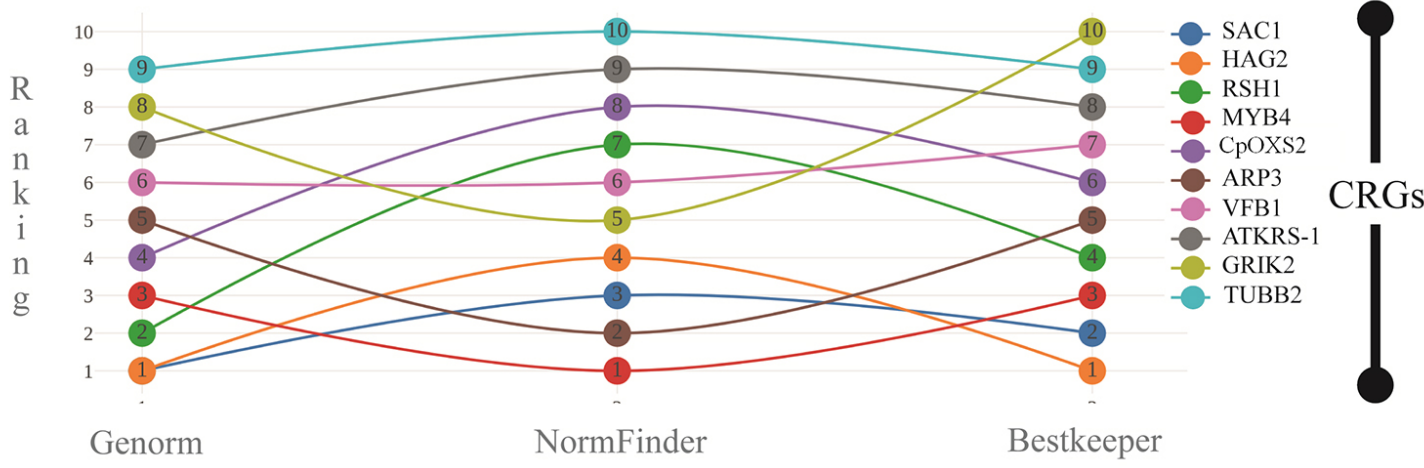

Genorm NormFinder Bestkeeper

C.

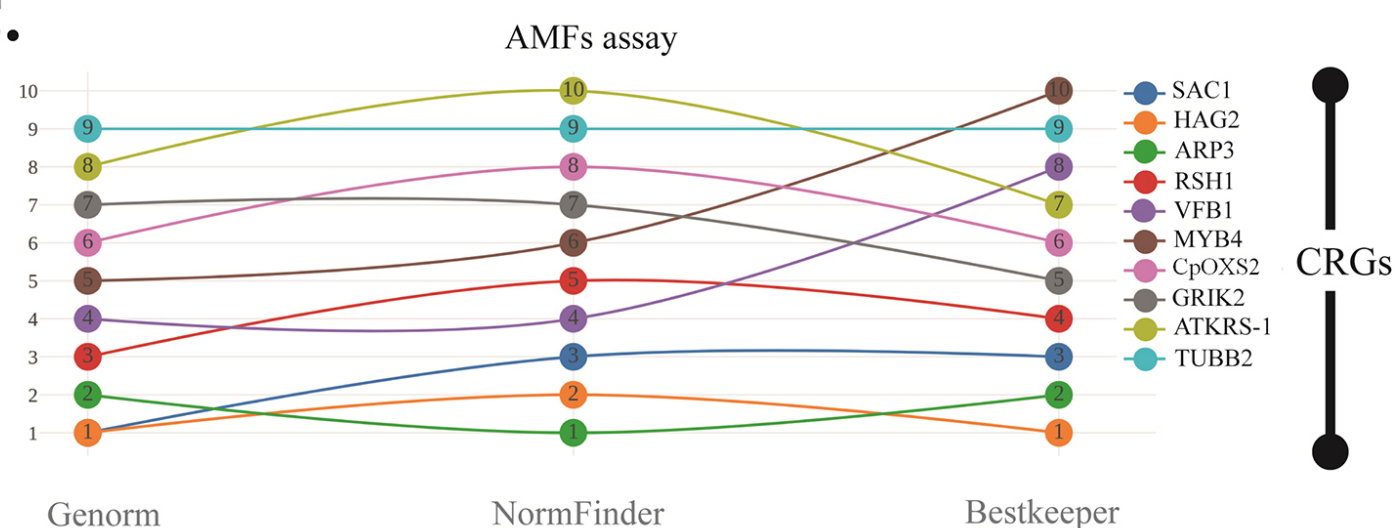

Figure 4 - Ranking of 10 candidate reference genes (CRGs) among softwares (geNorm, NormFinder, and BestKeeper). A- Global (Salt + arbuscular mycorrhizal fungi, AMF); B- Salt; C- AMF assay.

Related Protein 2/3 (ARP2/3) complex (Staiger and Blanchoin, 2006). Arabidopsis ARP $2 / 3$ complex subunits have also been reported to be involved with the stomatal movement (Li et al., 2014), salt stress (Zhao et al., 2013) and root hair development (Mathur, 2003). Root hair growth under certain conditions is disturbed in Arp2/3 mutants. ARP3 is also part of the ARP3/ DISTORTED1 (DIS1) complex that plays different roles in gravitropism and phototropism (Reboulet et al., 2010). ARP3/ DIS1 takes part in amyloplastic sedimentation by affecting local apparent viscosity in the central columella cells and in asymmetric auxin redistribution across the root tips through the modulation of auxin efflux carriers, such as PIN cycling
(Zou et al.,2016). Biochemical, genetic, and functional studies have revealed that actin-related proteins play diverse and significant roles in processes of vesicle motility, mitosis, actin filament dynamics, and modulation of chromatin structure. They are related to basic cell functions (Muller et al., 2005).

Putative GTP diphosphokinase, chloroplastic ( $\mathrm{RSH}$ ) was indicated by geNorm for salt condition normalization. Several studies have shown that plant RSH proteins are predominantly located in chloroplasts and plastids (Boniecka et al., 2017). This gene is involved with a fast plant (p) ppGpp (guanosine tetraphosphate/pentaphosphate) regulationmediated response to pathogen attack and other stresses. 
It belongs to the RelA/SpoT family (Boniecka et al., 2017). RSH1 seems to function as the major (p)ppGpp hydrolase in plants (Sugliani et al., 2016). The AtRSH genes are the first eukaryotic homologs of bacterial RelA/SpoT genes described to date (van der Biezen et al., 2000). Although (p)ppGpp appears to contribute to normal plant growth and development (Sugliani et al., 2016), it may also have stress-related functions. Levels of (p)ppGpp have been shown to increase in response to abiotic stress and to stress-related plant hormones (Ihara et al., 2015). However, in our study, this gene exhibited a constitutive expression pattern, being a suitable RG for $C$. pyramidale under the analyzed conditions.

For validation in all sequenced libraries (Salt30 min, $2 \mathrm{~h}$, 11d, and AMF30), the $H A G 2, S A C 1$ and $A R P 3$ were used to normalize the expression of two target transcripts up-regulated in Salt2h: ethylene-responsive transcription factor $(R A P 2-3)$ and Putative auxin efflux carrier component 8 (PIN8).

$R A P 2-3$ belongs to the superfamily AP2/ERF and the subfamily ERF. Transcription factors interact with cis-elements in the promoter regions of stressed-genes, inducing the expression of several genes and resulting in tolerance to stress (Wu et al., 2014). Specifically, AP2/ERF is one of the largest plant transcription factor families participating in plant development and resistance to biotic and abiotic stresses. It has been characterized based on either one or two AP2 domains, where the ERF subfamily has one AP2 domain (Pan et al., 2019). Plant hormones as salicylic acid (SA), methyl-jasmonate acid (MeJA), 1-aminocyclopropanecarboxylic acid (ACC), and abscisic acid (ABA), besides abiotic (including $\mathrm{NaCl}$ ) and biotic stresses, could induce the expression of RAP2-3 gene (Pan et al., 2019). In addition, Papdi et al. (2015) observed in $A$. thaliana that the stabilized RAP2 transcription factors, including $R A P 2-3$, can prolong the ABA-mediated activation of a subset of osmotic responsive genes.

The other target transcript tested in our study was a putative auxin efflux carrier component 8 (PIN8). The spatio-temporal control of auxin levels is fundamental for developmental events such as organ initiation, embryogenesis, and root differentiation. PIN8 (as PIN5 and PIN6) is predominantly located in the endoplasmic reticulum, although plasma membrane location cases have also been reported for PIN5 and PIN8 (Ganguly et al., 2014). PIN5, 6 and 8 are not directly involved with the cell-to-cell auxin transport but play a role in the intracellular regulation of auxin homeostasis by working together with members of the PIN-LIKE auxin efflux carriers (Barbez et al., 2012). In Arabidopsis, PIN proteins are involved with the crosstalk of auxin, ethylene, cytokinin, and strigolactone in root development and abiotic stresses (Wang et al., 2009; Shen et al., 2010; Yue et al., 2015). The capacity of PIN8 to change the composition of the auxin pool and to limit auxin availability for transcriptional gene regulation was evidenced in tobacco plants and Arabidopsis using dominant interference by overexpression (Dal Bosco et al., 2012). The PIN genes have been reported to play a crucial role in plants adapted the growth environment by response to several abiotic stress, such as salt stress (Habets and Offringa, 2014). Hu et al. (2021) observed the up-regulation in PIN8 along drought stress, including the time collection of $48 \mathrm{~h}$, in leaves of 3 months-old Liriodendron chinense. Our study brings the new insight of PIN8 related to salt stress in the root tissue.

\section{Conclusion}

We have tested the expression stabilities of 10 candidate reference genes (CRGs) required for reliable normalization in root tissues of an important woody legume tree representative of semiarid areas - Cenostigma pyramidale. The CRGs were tested in different experimental conditions, including salt stress and associated with arbuscular mycorrhizal fungi. Based on this data, for global and AMF assays $H A G 2, S A C 1$, and $A R P 3$ are recommended, while salt stress assay $H A G 2$, $S A C 1$, and RHS1 are the most suitable reference genes for normalization of expression analysis. Our results highlight the importance of selecting and validating reliable reference genes for an accurate interpretation of transcriptomic data. Also, depending on the treatments analyzed, the most reliable reference genes may change.

\section{Acknowledgments}

The authors thank the Centro de Referência para Recuperação de Áreas Degradadas (CRAD) for supplying the seeds of the studied species. GF would like to thank the Fundação de Amparo à Ciência e Tecnologia do Estado de Pernambuco (FACEPE) for the scholarship (BFP - 0010-2.03/17). This study was funded by FACEPE (APQ/PRONEM, Grant number 03362.03/14) and Coordenação de Aperfeiçoamento de Pessoal de Nível Superior (CAPES), Program BioComputacional (Grant number 88882.160046/2013-01), Conselho Nacional de Desenvolvimento Científico e Tecnológico (CNPq, Grant number 307129/2015-2]. AMBI and MGS would like to thank the Conselho Nacional de Desenvolvimento Científico e Tecnológico (CNPq) for the fellowship granted. Computing and networking infrastructure was provided by Calcul Québec and Compute Canada.

\section{Conflict of Interest}

The authors declare no conflict of interest.

\section{Author Contributions}

GF, AMBI, MGS and VP conceived and designed the experiments. AMBI and MGS supervised the study. GF performed the experiment. GF, VP, LLL and EAK performed the wet lab analysis. GF, DALM and JPBN performed the bioinformatics analysis. GF, JRCFN and VP wrote the manuscript. All authors read and approved the final manuscript.

\section{References}

Alviano WS, Alviano DS, Diniz CG, Antoniolli AR, Alviano CS, Farias LM, Carvalho MAR, Souza MMG and Bolognese AM (2008) In vitro antioxidant potential of medicinal plant extracts and their activities against oral bacteria based on Brazilian folk medicine. Arch Oral Biol 53:545-552.

Amorim LLB, Ferreira-Neto JRC, Bezerra-Neto JP, Pandolfi V, Araújo FT, Silva Matos MK, Santos MG, Kido EA and Benko-Iseppon, AM (2018) Cowpea and abiotic stresses: Identification of reference genes for transcriptional profiling by qPCR. Plant Methods 14:88.

Andersen CL, Jensen JL and Ørntoft TF (2004) Normalization of real-time quantitative reverse transcription-PCR data: A model-based variance estimation approach to identify genes suited for normalization, applied to bladder and colon cancer data sets. Cancer Res 64:5245-5250. 
Barbez E, Kubeš M, Rolčík J, Béziat C, Pěnčík A, Wang B, Rosquete MR, Zhu J, Dobrev PI, Lee Y et al. (2012) A novel putative auxin carrier family regulates intracellular auxin homeostasis in plants. Nature 485:119-122.

Biassoni R and Raso A (eds) (2014) Quantitative Real-Time PCR: Methods and Protocols. 1st ed. Methods in Molecular Biology. Humana Press, New York, 231 p.

Bolger AM, Lohse M and Usadel B (2014) Trimmomatic: A flexible trimmer for Illumina sequence data. Bioinformatics 30:2114 2120.

Boniecka J, Prusińska J, Dąbrowska GB and Goc A (2017) Within and beyond the stringent response-RSH and (p)ppGpp in plants. Planta 246:817-842.

Bourgey M, Dali R, Eveleigh R, Chen KC, Letourneau L, Fillon J, Michaud M, Caron M, Sandoval J, Lefebvre F et al. (2018) GenPipes: an open-source framework for distributed and scalable genomic analyses. Gigascience 8:giz037.

Brinkhof B, Spee B, Rothuizen J and Penning LC (2006) Development and evaluation of canine reference genes for accurate quantification of gene expression. Anal Biochem 356:36-43.

Bustin SA, Benes V, Garson JA, Hellemans J, Huggett J, Kubista M, Mueller R, Nolan T, Pfaffl MW, Shipley GL et al. (2009) The MIQE guidelines: Minimum information for publication of quantitative real-time PCR experiments. Clin Chem 55: 611-622.

Chang S, Puryear J and Cairney J (1993) A simple and efficient method for isolating RNA from pine trees. Plant Mol Biol Report 11:113-116.

Chen J (2007) Roles of dynamic and reversible histone acetylation in plant. Biochim Biophys Acta 1769:295-307

Coêlho MRV, Rivas R and Ferreira-Neto JRC, Pandolfi V, BezerraNeto JP, Benko-Iseppon AM and Santos MG (2019) Reference genes selection for Calotropis procera under different salt stress conditions. PLoS One 14:e0215729.

Dal Bosco C, Dovzhenko A, Liu X, Woerner N, Rensch T, Eismann M, Eimer S, Hegermann J, Paponov IA, Ruperti B et al. (2012) The endoplasmic reticulum localized PIN8 is a pollen-specific auxin carrier involved in intracellular auxin homeostasis. Plant J 71:860-870.

De Albuquerque UP, De Lima Araújo E, El-Deir ACA, Lima ALA, Souto A, Bezerra BM, Ferraz EMN, Freire EMX, Sampaio EVSB and Las-Casas, FMG (2012) Caatinga revisited: Ecology and conservation of an important seasonal dry forest. Sci World J 2012:205182.

De Craene JO, Bertazzi DL, Bär S and Friant S (2017) Phosphoinositides, major actors in membrane trafficking and lipid signaling pathways. Int J Mol Sci 18:634

Despres B, Bouissonnié F, Wu HJ, Gomord V, Guilleminot J, Grellet F, Berger F, Delseny M, Devic M et al.(2003) Three SAC1-like genes show overlapping patterns of expression in Arabidopsis but are remarkably silent during embryo development. Plant J 34:293-306.

DeWald DB (2001) Rapid Accumulation of Phosphatidylinositol 4,5-Bisphosphate and Inositol 1,4,5-Trisphosphate Correlates with Calcium Mobilization in Salt-Stressed Arabidopsis. Plant Physiol 126:759-769.

Dheda K, Huggett JF, Chang JS, Kim LU, Bustin SA, Johnson MA, Rook GAW and Zumla A (2005) The implications of using an inappropriate reference gene for real-time reverse transcription PCR data normalization. Anal Biochem 344:141-143.

Falcão HM, Medeiros CD, Silva BLR, Sampaio EVSB, AlmeidaCortez JS and Santos MG (2015) Phenotypic plasticity and ecophysiological strategies in a tropical dry forest chronosequence: A study case with Poincianella pyramidalis. For Ecol Manage 340:62-69.
Frosi G, Barros VA, Oliveira MT, Santos M, Ramos DG, Maia LC and Santos MG (2016) Symbiosis with AMF and leaf P i supply increases water deficit tolerance of woody species from seasonal dry tropical forest. J Plant Physiol 207:84-93.

Frosi G, Barros VA, Oliveira MT, Santos M, Ramos DG, Maia LC and Santos MG (2018) Arbuscular mycorrhizal fungi and foliar phosphorus inorganic supply alleviate salt stress effects in physiological attributes, but only arbuscular mycorrhizal fungi increase biomass in woody species of a semiarid environment. Tree Physiol 38:25-36.

Frosi G, Ferreira-Neto JRC, Bezerra JP, Pandolfi V, da Silva MD, Morais DAL, Benko-Iseppon AM and Santos MG (2021) Transcriptome of roots, a woody legume, under different salt stress times. Physiol Plantarum [in press].

Fuentes A, Ortiz J, Saavedra N, Salazar LA, Meneses C and Arriagada C (2016) Reference gene selection for quantitative realtime PCR in Solanum lycopersicum L. inoculated with the mycorrhizal fungus Rhizophagusir regularis. Plant Physiol Biochem 101:124-131.

Ganguly A, Park M, Kesawat MS and Cho H-T (2014) Functional analysis of the hydrophilic loop in intracellular trafficking of Arabidopsis PIN-FORMED proteins. Plant Cell 26:1570-1585.

Gutierrez L, Mauriat M, Pelloux J, Bellini C and Van Wuytswinkel $\mathrm{O}$ (2008) Towards a systematic validation of references in Real-Time RT-PCR. Plant Cell Online 20:1734-1735.

Haas BJ, Papanicolaou A, Yassour M, Grabherr M, Blood FD, Bowden J, Couger MB, Eccles D, Li B, Lieber M et al. (2013) De novo transcript sequence reconstruction from RNA-seq using the Trinity platform for reference generation and analysis. Nat Protoc 8:1494-512.

Habets MEJ and Offringa R (2014) PIN-driven polar auxin transport in plant developmental plasticity: a key target for environmental and endogenous signals. New Phytol 203:362-377.

Haigney A, Ricketts MD and Marmorstein R (2015) Dissecting the molecular roles of histone chaperones in histone acetylation by type B histone acetyltransferases (HAT-B). J Biol Chem 290:30648-30657.

Hellemans J, Mortier G, De Paepe A, Speleman F and Vandesompele J (2007) qBase relative quantification framework and software for management and automated analysis of real-time quantitative PCR data. Genome Biol 8:R19.

Hsu F and Mao Y (2013) The Sac domain-containing phosphoinositide phosphatases: structure, function, and disease. Front Biol 8:395-407.

Hu L, Wang P, Xiofei L, Wu W, Zhang J, Pan Y, Cheng T, Shi J and Chen J (2021) The PIN gene family in relic plant $L$. chinense: Genome-wide identification and gene expression profiling in different organizations and abiotic stress responses. Plant Physiol Bioch 162:634-646.

Huang X, Li S and Zhan A (2019) Genome-wide identification and evaluation of reference genes for gene expression analysis under temperature and salinity stresses in Ciona savignyi. Front Genet 10:71.

Huber W, Carey VJ, Gentleman R, Anders S, Carlson M, Carvalho BS, Bravo HC, Davis S, Gatto L, Girke T et al. (2015) Allosteric inhibition of Hypoxia Inducible Factor-2 with small molecules. Nat Chem Biol 12:115-121.

Ihara Y, Ohta $\mathrm{H}$ and Masuda S (2015) A highly sensitive quantification method for the accumulation of alarmone ppGpp in Arabidopsis thaliana using UPLC-ESI-qMS/MS. J Plant Res 128:511-518.

Kozera B and Rapacz M (2013) Reference genes in real-time PCR. J Appl Genet 54:391-406.

Li X, Li JH, Wang W, Chen NZ, Ma T-S, Xi Y-N, Zhang X-L, Lin H-F, Bai Y, Huang S-J and Chen Y-L, (2014) ARP2/3 complex-mediated actin dynamics is required for hydrogen peroxide-induced stomatal closure in Arabidopsis. Plant Cell Environ 37:1548-1560. 
Maroufi A, Van Bockstaele E and De Loose M (2010) Validation of reference genes for gene expression analysis in chicory (Cichorium intybus) using quantitative real-time PCR. BMC Mol Biol 11:15.

Mathur J (2003) Mutations in Actin-Related Proteins 2 and 3 affect cell shape development in Arabidopsis. Plant Cell Online 15:1632-1645.

Muller J, Oma Y, Vallar L, Friederich E, Poch O and Winsor B (2005) Sequence and comparative genomic analysis of actinrelated proteins. Mol Biol Cell 16:5736-5748.

Papdi C, Pérez-Salamó I, Joseph MP, Giuntoli B, Bögre L, Koncz $\mathrm{C}$ and Szabados L (2015) The low oxygen oxidative and osmotic stress responses synergistically act through the ethylene response factor VII genes RAP2.12, RAP2.2 and RAP2.3. Plant J. 82:772-784.

Pan D-L, Wang G, Wang T, Jia Z-H, Guo Z-R and Zhang J-Y (2019) AdRAP2.3, a Novel Ethylene Response Factor VII from Actinidia deliciosa, enhances waterlogging resistance in transgenic tobacco through improving expression levels of PDC and ADH genes. Int J Mol Sci 20:1189.

Parthun MR (2007) Hat1: The emerging cellular roles of a type B histone acetyltransferase. Oncogene 26:5319-5328.

Pfaffl MW, Horgan GW and Dempfle L (2002) Relative expression software tool (REST) for group-wise comparison and statistical analysis of relative expression results in real-time PCR. Nucleic Acids Res 30:e36

Pfaffl MW, Tichopad A, Prgomet C and Neuvians TP (2004) Determination of most stable housekeeping genes, differentially regulated target genes and sample integrity: BestKeeper - Excel spreadsheet tool using a Repeated Pairwise Correlation and Regression Analysis. Biotechnol Lett 26:509-515.

Pfluger J and Wagner D (2008) Histone modifications and dynamic regulation of genome accessibility in plants. Curr Opin Plant Biol 10:645-652

Pombo MA, Ramos RN, Zheng Y, Fei Z, Martin GB and Rosli HG. (2019) Transcriptome-based identification and validation of reference genes for plant-bacteria interaction studies using Nicotiana benthamiana. Sci Rep 9:1632.

Reboulet JC, Kumar P and Kiss JZ (2010) DIS1 and DIS2 play a role in tropisms in Arabidopsis thaliana. Environ Exp Bot 67:474-478.

Robinson MD, McCarthy DJ and Smyth GK (2009) edgeR: A Bioconductor package for differential expression analysis of digital gene expression data. Bioinformatics 26:139-140.

Santos JS, Mendes SS, Conde DC, Delmondez RC, Mann RS and Thomazzi SM (2012) Genetic diversity assessment of Poincianella pyramidalis (Tul.) L.P. Queiroz accessions using RAPD markers. Scientia Plena 8:030202.

Santos MG, Oliveira MT, Figueiredo KV, Falcão HM, Arruda ECP, Almeida-Cortez J, Sampaio EVSB, Ometto JPHB, Menezes RSC, Oliveira AFM et al. (2014) Caatinga, the Brazilian dry tropical forest: Can it tolerate climate changes? Theor Exp Plant Physiol 26:83-99.

Shen CJ, Bai YH, Wang SK, Zhang SN, Wu YR, Chen M, Jiang DA and Qi YH (2010) Expression profile of PIN, AUX/LAX and PGP auxin transporter gene families in Sorghum bicolor under phytohormone and abiotic stress. FEBS J 277:2954-2969.

Sinha P, Singh VK, Suryanarayana V, Krishnamurthy L, Saxena RK and Varshney RK (2015) Evaluation and validation of housekeeping genes as reference for gene expression studies in pigeonpea (Cajanus cajan) under drought stress conditions. PLoS One 10:e122847.

Staiger CJ and Blanchoin L (2006) Actin dynamics: old friends with new stories. Curr Opin Plant Biol 9:554-562.
Strahl T and Thorner J (2007) Synthesis and function of membrane phosphoinositides in budding yeast, Saccharomyces cerevisiae. Biochim Biophys Acta 1771:353-404.

Sugliani M, Abdelkefi H, Ke H, Bouveret E, Robaglia C, Caffarri S and Field B (2016) An ancient bacterial signaling pathway regulates chloroplast function to influence growth and development in Arabidopsis. Plant Cell 28:661-679.

US Salinity Laboratory (ed) (1954) Diagnosis and improvement of saline and alkali soils. Washington, United States Department of Agriculture.

van der Biezen EA, Sun J, Coleman MJ, Bibb MJ and Jones JDG (2000) Arabidopsis RelA/SpoT homologs implicate (p)ppGpp in plant signaling. Proc Natl Acad Sci USA 97:3747-52.

Vandesompele J, De Preter K, Pattyn F, Poppe B, Van Roy N, Paepe AD and Speleman F (2002) Accurate normalization of realtime quantitative RT-PCR data by geometric averaging of multiple internal control genes. Genome Biol 3:research0034.

Vilela LMB, Silva CAS, Roldan Filho RS, Araujo SS, Ferreira-Neto JRC, Oliveira WD, Amorim LLB, Pandolfi VP and BenkoIseppon AM (2020). Cenostigma pyramidale: ethnomedicinal properties and perspectives on a legume tree highly adapted to semiarid 'Caatinga' region. In: Rai M, Bhattarai S and Feitosa CM (eds) Wild Plants: The treasure of natural healers. Chapter 11. CRC Press, Boca Raton, chapter 11.

Wang J-R, Hu H, Wang G-H, Li J, Chen J-Y and Wu P (2009) Expression of PIN genes in rice (Oryza sativa L.): Tissue specificity and regulation by hormones. Mol Plant 2:823-831.

Wang M-Le, Li Q-H, Xin HH, Xin H-H, Chen X, Zhu XJ and Li X-H (2017) Reliable reference genes for normalization of gene expression data in tea plants (Camellia sinensis) exposed to metal stresses. PLoS One 12:e0175863.

Wu D, Ji J, Wang G, Guan C and Jin C (2014) LchERF, a novel ethylene-responsive transcription factor from Lycium chinense, confers salt tolerance in transgenic tobacco. Plant Cell Rep 33:2033-2045.

Yang Q, Yin J, Li G, Qi L, Yang F, Wang R and Li G (2014) Reference gene selection for qRT-PCR in Caragana korshinskii Kom. under different stress conditions. Mol Biol Rep 41:2325-2334.

Yang Z, Chen Y, Hu B, Tan Z and Huang B (2015) Identification and validation of reference genes for quantification of target gene expression with quantitative real-time PCR for tall fescue under four abiotic stresses. PLoS One 10:e0119569

Yue R, Tie S, Sun T, Zhang L, Yang Y, Qi J, Yan S, Han X, Wang H and Shen C (2015) Genome-wide identification and expression profiling analysis of ZmPIN, ZmPILS, ZmLAX and ZmABCB auxin transporter gene families in maize (Zea mays L.) under various abiotic stresses. PLoS One 10:e0118751.

Zhao Y, Pan Z, Zhang Y, Qu X, Zhang Y, Yang Y, Jiang X, Huang S, Yuan M, Schumaker KS et al. (2013) The Actin-Related Protein $2 / 3$ Complex regulates mitochondrial-associated calcium signaling during salt stress in Arabidopsis. Plant Cell 25:4544-4559.

Zou JJ, Zheng Z-Y, Xue S, Li H-H, Wang Y-R and Le J. (2016) The role of Arabidopsis Actin-Related Protein 3 in amyloplast sedimentation and polar auxin transport in root gravitropism. J Exp Bot 67:5325-5337

\section{Internet Resources}

Andrews, S (2010). FastQC: A Quality Control Tool for High Throughput Sequence Data [Online], http://www. bioinformatics.babraham.ac.uk/projects/fastqc/

Primer 3 Plus, http://www.bioinformatics.nl/cgi-bin/primer3plus/ primer3plus.cgi (accessed 6 July 2019). 
REST 2009 (2009) Software for gene expression analysis using realtime PCR data from the Rotor-Gene ${ }^{\circledR} \mathrm{Q}$ and other cyclers, https://www.gene-quantification.de/rest-2009.html.

Sequence Read Archive (SRA), https://www.Ncbi.Nlm.Nih.Gov/ traces/study/?Acc=prjna552047 (accessed 24 July 2019).

\section{Supplementary material}

The following online material is available for this article: Table S1 - MIQE checklist for authors, reviewers and editors.
Table S2 - Cq values obtained from reference genes.

Figure S1- Melting temperature of ten candidates reference genes (RGs) and two target transcripts (TTs).

Associate Editor: Rogerio Margis

License information: This is an open-access article distributed under the terms of the Creative Commons Attribution License (type CC-BY), which permits unrestricted use, distribution and reproduction in any medium, provided the original article is properly cited. 